\title{
Glucose Metabolism of the Isolated Eccrine Sweat Gland
}

\author{
II. THE RELATION BETWEEN GLUCOSE METABOLISM \\ AND SODIUM TRANSPORT
}

\author{
Kenzo Sato and Richard L. Dobson \\ From the Department of Dermatology, University of Oregon Medical School, \\ Portland, Oregon 97201, and the Department of Dermatology and Physiology, \\ University of Nijmegen School of Medicine, Nijmegen, The Netherlands
}

\begin{abstract}
A в S T R A C T This paper attempts to further clarify the characteristics of Mecholyl- or epinephrine-stimulated glucose metabolism in the isolated monkey eccrine sweat gland with special emphasis on its relationship to increased sodium transport. The Mecholyl- or epinephrine-stimulated glucose metabolism (as estimated by either lactate or ${ }^{14} \mathrm{CO}$ e production or both) is seen only in the secretory coil and not in the duct. It is markedly suppressed in the absence of glucose, $\mathrm{Na}^{+}$, or $\mathrm{K}^{+}$. It is inhibited by ouabain $\left(10^{-3} \mathrm{M}\right)$ and partially suppressed in a low-sodium $(40 \mathrm{mM})$, high-potassium $(100 \mathrm{mM})$ medium.
\end{abstract}

2,4-dinitrophenol $\left(10^{-4} \mathrm{M}\right)$ reverses ouabain-induced inhibition of lactate and ${ }^{14} \mathrm{CO}_{2}$ production but only partially reverses inhibition induced by $\mathrm{Na}^{+}+\mathrm{K}^{+}$deprivation, indicating that metabolic inhibition by ouabain is secondary to the inhibition of sodium transport. There is no synergism between Mecholyl and epinephrine. The absence of any significant inhibitory effects by acetazolamide (Diamox) or $\mathrm{HCO}_{3}{ }^{-}$-free media suggests that $\mathrm{H}^{+}$transport may not be important in sweat gland function. In contrast to a report by Wolfe et al., human eccrine sweat glands show considerable oxidative activity $\left({ }^{14} \mathrm{CO}_{2}\right.$ production of $0.42-0.72 \mathrm{nmol} /$ gland $\left./ \mathrm{h}\right)$. These observations are discussed in terms of the linkage between sweat gland energy metabolism and sodium transport.

Dr. Sato's present address is: Max-Planck-Institute für Biophysik, 6 Frankfurt a.M. 70, Germany.

Dr. Dobson's present address is: Department of Dermatology, the State University of New York at Buffalo, School of Medicine, Buffalo, N. Y. 14203.

Received for publication 5 December 1972 and in revised form 5 April 1973.

\section{INTRODUCTION}

When freshly isolated eccrine sweat glands are incubated aerobically in vitro, cholinergic and adrenergic drugs markedly stimulate both lactate and ${ }^{14} \mathrm{CO}_{2}$ production (1). Atropine and phentolamine, specific pharmacologic inhibitors of these respective drugs, and ouabain, an inhibitor of $\left(\mathrm{Na}^{+}+\mathrm{K}^{+}\right)$-ATPase, abolish these stimulatory effects (1). Under physiological conditions the oxidation of glucose is coupled to the regeneration of ATP and orthophosphate (2). This led us to assume that the stimulation of glucose metabolism by cholinergic or adrenergic drugs resulted from an enhanced sodium transport, because the major function of the eccrine sweat gland is to secrete water and electrolytes. This assumption was supported by the stoichiometric relation between net sodium flux and ATP formation by the eccrine sweat gland after cholinergic stimulation (3). However, a similar stoichiometric relation does not apply after adrenergic stimulation, because the in vivo sweat rate is disproportionately lower than the amount of glucose metabolized in vitro.

In these studies we attempted to elucidate the mechanisms by which cholinergic and adrenergic drugs stimulate in vitro metabolism of the eccrine sweat gland, especially in terms of its relationship to sodium transport. The studies include an investigation of a differential metabolic response of the duct and secretory coil and of the effects of electrolytes, 2,4-dinitrophenol (DNP,' Merck Chemical Div., Merck \& Co., Rahway, N. J.)

${ }^{1}$ Abbreviations used in this paper: DNP, dinitrophenol; KRB, Krebs-Ringer bicarbonate solution; KT, KrebsTris buffer; POPOP, $p$-bis-2,5-phenyloxazoilibenzene; PPO, 2,5-diphenyloxazole. 
and acetazolamide (Diamox, Lederle Laboratories, Pearl River, N. Y.) on glucose metabolism of the sweat gland coil (duct + secretory coil) in vitro. We also compared the glucose metabolism of human eccrine sweat glands to that of monkey sweat glands. Evidence was obtained to suggest that the metabolic stimulation in incubated eccrine sweat gland by cholinergic and adrenergic drugs reflects mainly sodium transport, an idea supported by the recent observation ${ }^{2}$ that both cholinergic and adrenergic drugs induce sweating from an isolated eccrine sweat gland in vitro.

\section{METHODS}

\section{Glucose metabolism of the isolated monkey palm eccrine sweat gland}

Skin biopsy specimens $(1.5 \mathrm{~cm} \times 0.5 \mathrm{~cm})$ were obtained from the palm of 22 adult rhesus monkeys and 4 adult stump-tailed macaques tranquilized with phencyclidine $\mathrm{HCl}$ (Sernyl, Parke, Davis \& Co., Detroit, Mich.). In most monkeys, several skin specimens were excised from the same palm. In such cases rebiopsy was performed after at least $4 \mathrm{wk}$ and the area of skin adjacent to the previous excision was avoided. Either Krebs-Tris buffer (KT) $140 \mathrm{mM}$ $\mathrm{NaCl}, 5 \mathrm{mM} \mathrm{KCl}, 1.4 \mathrm{mM} \mathrm{CaCl}, 2.5 \mathrm{mM} \mathrm{MgCl}_{2}, 20 \mathrm{mM}$

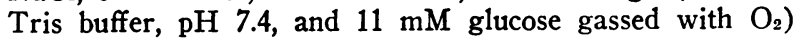
or Krebs-Ringer bicarbonate (KRB) $(125 \mathrm{mM} \mathrm{NaCl}, 5$ $\mathrm{mM} \mathrm{KCl}, 1.2 \mathrm{mM} \mathrm{MgCl}, 1.0 \mathrm{mM} \mathrm{CaCl}, 25 \mathrm{mM} \mathrm{NaHCO}$, $1.2 \mathrm{mM} \mathrm{NaH} \mathrm{PO}_{4}$, and $11 \mathrm{mM}$ glucose, $\mathrm{pH} 7.4$ gassed with $95 \% \mathrm{O}_{2}$ and $5 \% \mathrm{CO}_{2}$ ) was used as the incubation medium unless otherwise specified.

Immediately after excision, the skin specimens were sliced freehand with a razor blade and were rinsed in several changes of either ice-cold KT or KRB solution. Fresh, unstained sweat gland coils (secretory portion plus coiled duct) were isolated in either ice-cold KT or KRB under a stereoscopic microscope using two pairs of Dumont No. 5 stainless steel tweezers (Dumont Tweezer, Hammel, Riglander \& Co., Hudson, N. Y.) $(1,4)$. The method for sweat gland incubation and determination of lactate and $\mathrm{CO}_{2}$ production have been described in detail (1).

When only lactate production was studied, three to five sweat gland coils were incubated in a test tube containing 200 or $400 \mu 1$ of an appropriate Tris-buffered medium with or without the addition of drugs. All incubations were performed in duplicate for $1 \mathrm{~h}$ in a closed water bath at $38^{\circ} \mathrm{C}$ unless otherwise specified. Air was used as the gas phase. ${ }^{14} \mathrm{CO}_{2}$ production was measured by a method modified from that of Adachi and Uno (5). [6- $\left.{ }^{14} \mathrm{C}\right]$ glucose (The Radiochemical Centre, Amersham, England, sp. act. $=3.0 \mathrm{mCi}$ / $\mathrm{mM}$ ) in appropriate dilution (usually $0.15 \mathrm{mCi} / \mathrm{mM}$ glucose in a final concentration) was used as a tracer. When KRB was used as a medium, an incubation test tube $(8 \mathrm{~mm}$ ID $\times 50 \mathrm{~mm}$ ) was filled with $5 \% \mathrm{CO}_{2}$ and $95 \% \mathrm{O}_{2}$, promptly capped with Parafilm (American Can Co., Neenah, Wis.), and connected to an upper test tube containing paper impregnated with hyamine hydroxide [ $p$-(diisobutylcresoxy-ethoxyethyl) dimethyl benzyl ammonium hydroxide, Packard Instrument Co., Inc., Downers Grove, Ill.] by a rubber sleeve. The trapping of $\mathrm{CO}_{2}$ by hyamine hydroxide was thus prevented

\footnotetext{
${ }^{2}$ Sato, K. 1973. Sweat induction from an isolated eccrine sweat gland. Am. J. Phy'siol. In press.
}

during the incubation period and the $\mathrm{pH}$ of media was maintained at $7.4 \pm 0.03$. After a 1 - $\mathrm{h}$ incubation at $38^{\circ} \mathrm{C}$, the thin layer of Parafilm was torn with a needle inserted through the rubber sleeve and the gas phase of the incubation tube exposed to the hyamine hydroxide-impregnated paper. $30 \mu 1$ of cold $40 \%$ trichloracetic acid was injected through the rubber sleeve with a needle and syringe to generate $\mathrm{CO}_{2}$, which was completely trapped by the hyamine hydroxide-impregnated paper during the next $4 \mathrm{~h}$. An aliquot of $100 \mu \mathrm{l}$ was taken from the incubation medium for the enzymatic determination of lactate (6) except that fluorescence was measured with a Farrand fluorometer (Farrand Optical Co., Inc., Valhalla. N. Y.). The ${ }^{14} \mathrm{CO}_{2}$-hyamine in the filter paper was eluted with scintillation fluid consisting of toluene (Merck), $0.5 \%$ 2,5-diphenyloxazole (PPO) (Packard) and 0.03\% $p$-bis-2,5-phenyloxazoilibenzene (POPOP) (Packard) and counted with a Nuclear-Chicago liquid scintillation counter (Nuclear-Chicago Corp., Des Plaines, Ill.) fitted with external standards for correction of quenching and calculation of the radioactivity. The same procedure was used when $\mathrm{KT}$ was used as a medium except that an incubation test tube was filled with $100 \% \mathrm{O}_{2}$ and connected directly to an upper test tube without Parafilm. To exclude the possible contribution of bacterial metabolism during the incubation, all values of lactate and ${ }^{14} \mathrm{CO}_{2}$ production were compared with simultaneously incubated samples consisting of either incubation medium alone or medium containing boiled sweat glands. Unless otherwise described, both lactate and ${ }^{14} \mathrm{CO}_{2}$ production were expressed as nanomoles per gland per $\mathrm{h}$, because in monkeys the size of the sweat gland was rather uniform between 25 and $30 \mu \mathrm{g}$ wet weight/gland for rhesus monkeys (3) and 30-35 $\mu \mathrm{g} / \mathrm{gland}$ for stump-tailed macaques with a mean protein content of $7.46 \%$ (4). In addition, despite the variation in the removal of attached collagen fiber, the difference in the dry weights of the glands in an individual rhesus monkey was rather small (mean $2.73 \pm 0.14$ (SE) $\mu \mathrm{g}$, range 2.2-3.5 $\mu \mathrm{g}(7)$.

The effect of glucose-free medium on lactate production. Sweat glands were isolated in ice-cold KT medium containing $5.5 \mathrm{mM}$ glucose within $30 \mathrm{~min}$ of excision to minimize a decrease in endogenous glycogen or glucose or both. Those sweat glands to be incubated in the glucose-free medium were washed briefly in ice-cold glucose-free KT medium and gently blotted before being transferred to the incubation test tubes.

The differential response of the duct and the secretory coil to Mecholyl and epinephrine. Approximately 60 freshly isolated, nonstained sweat gland coils were separated into the secretory coil and coiled duct in ice-cold $\mathrm{KT}$ as described previously (4). Approximately 10 segments of either secretory coil or duct were incubated in each test tube containing KT with or without Mecholyl (acetyl- $\beta$-methylcholine, Sigma Chemical Co., St. Louis, Mo.) or epinephrine (Sigma). 4-5 $\mathrm{h}$ was required from the time of biopsy to the beginning of incubation. Since the tissue size of the separated segments varied, the protein content of the tissue was determined in each test tube by the method of Lowry, Rosebrough, Farr, and Randall (8). Both ${ }^{14} \mathrm{CO}_{2}$ and lactate production were expressed as nanomoles per $\mu \mathrm{g}$ protein per hour (a single sweat gland coil contains approximately 2 $\mu \mathrm{g}$ protein).

The effect of $\mathrm{Na}^{+}$and $\mathrm{K}^{+}$deprivation in the medium on lactate production. Five incubation media were prepared by changing the $\mathrm{Na}^{+}$or $\mathrm{K}^{+}$concentrations in the $\mathrm{KT}$ medium; i.e., a complete $\mathrm{KT}$ medium, a $\mathrm{Na}^{+}$- and $\mathrm{K}^{+}$-free medium, in which $\mathrm{Na}^{+}$and $\mathrm{K}^{+}$were replaced by $140 \mathrm{mM}$ 


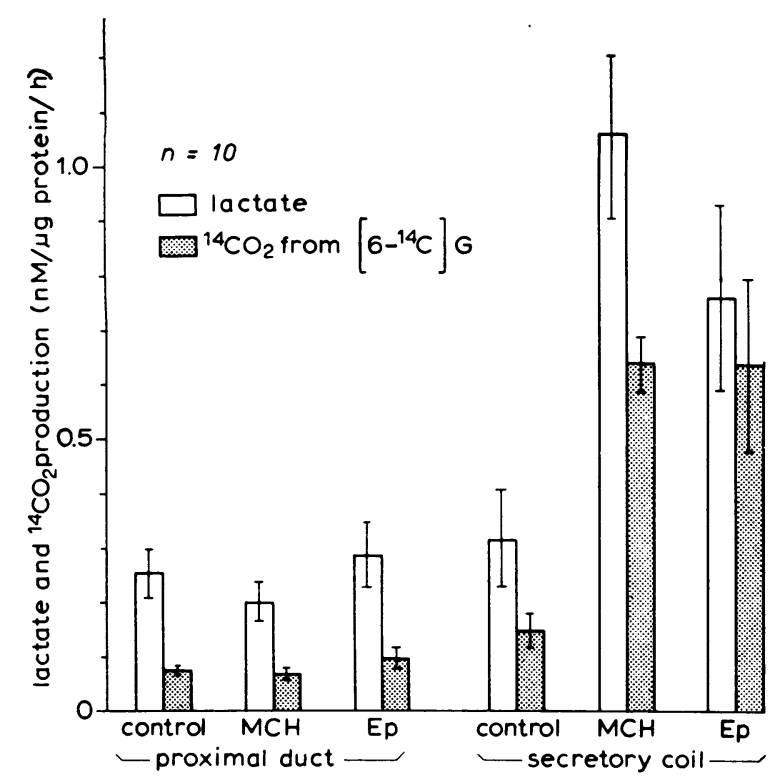

Figure 1 Lactate and ${ }^{14} \mathrm{CO}_{2}$ production in the coiled (proximal) duct and the secretory coil. The columns and vertical bars represent mean \pm SEM. Note that both lactate and ${ }^{14} \mathrm{CO}_{2}$ production are expressed as nanomoles per $\mu \mathrm{g}$ protein per hour. Unless otherwise stated, Mecholyl $(\mathrm{MCH})$ was added to a final concentration of $4.2 \times 10^{-4} \mathrm{M}$ and epinephrine (EP) to a final concentration of $5.5 \times 10^{-5} \mathrm{M}$ throughout the study. $n$, number of experiments. $\left[6-{ }^{14} \mathrm{C}\right] \mathrm{G}$, $\left[6-{ }^{14} \mathrm{C}\right]$ glucose.

choline chloride, a $\mathrm{Na}^{+}$-free, $140 \mathrm{mM} \mathrm{K} \mathrm{K}^{+}$medium, a 140 $\mathrm{mM} \mathrm{Na}{ }^{+}$and $\mathrm{K}^{+}$-free medium and a $40 \mathrm{mM} \mathrm{Na} \mathrm{Na}^{+}$and 100 $\mathrm{mM} \mathrm{K} \mathrm{K}^{+}$medium. The isolated sweat gland coils were quickly dipped in $150 \mathrm{mM}$ Tris buffer $(\mathrm{pH} 7.5)$ and blotted on ashless filter paper before transfer to the incubation medium.

The effect of $40 \mathrm{mM} \mathrm{Na}+100 \mathrm{mM} \mathrm{K} \mathrm{K}^{+}$medium on lactate production. In each experiment, two systems were run simultaneously. The first system, used as a control, consisted of duplicate incubation test tubes containing 400 $\mu \mathrm{KT}$ with or without Mecholyl. 10 sweat gland coils were incubated in each test tube for $10 \mathrm{~min}$ at $38^{\circ} \mathrm{C}$ and then placed in an ice bath. The sweat glands were collected as a batch, blotted with filter paper, quickly transferred to new test tubes containing the same medium as in the first incu-

TABLE I

Effect of Glucose in the Incubation Medium on Lactate Production

\begin{tabular}{lcc}
\hline \multirow{2}{*}{ Drug addition } & \multicolumn{2}{c}{ Medium } \\
\cline { 2 - 3 } & Glucose-containing & Glucose-free \\
\hline No drug addition & $0.64 \pm 0.06$ & $0.10 \pm 0.03$ \\
Mecholyl $\left(4.2 \times 10^{-6} \mathrm{M}\right)$ & $2.87 \pm 0.27$ & $0.08 \pm 0.03$ \\
Epinephrine $\left(5.5 \times 10^{-6} \mathrm{M}\right)$ & $1.16 \pm 0.29$ & $0.10 \pm 0.03$
\end{tabular}

The results are the mean $\pm \mathrm{SEM}$ of four experiments. All the values are expressed as nmol lactate/gland $/ \mathrm{h}$. bation period, and reincubated at $38^{\circ} \mathrm{C}$ for $10 \mathrm{~min}$. The same procedures were repeated for a third $10-\mathrm{min}$ incubation. The time required for transferring the sweat glands from one test tube to another was less than $1 \mathrm{~min}$. The second system was processed in the same manner except that $100 \mathrm{mM} \mathrm{K} \mathrm{K}^{+}+40 \mathrm{mM} \mathrm{Na} \mathrm{Na}^{+}$medium was used for the second $10-\mathrm{min}$ incubation instead of $\mathrm{KT}$ medium. After the incubation, aliquots were taken from the media for lactate determination.

The effect of DNP on the metabolic inhibition induced by ouabain or $\mathrm{Na}^{+}$and $\mathrm{K}^{+}$deprivation. The effects of varying concentrations of $\mathrm{DNP}$ were first tested on lactate production in $\mathrm{KT}$ media. Based on this dose-response study, the effect of $10^{-4} \mathrm{M}$ DNP, which gave the maximal stimulation of lactate production, on the metabolic stimulation induced by Mecholyl or epinephrine (in KRB) and on the metabolic inhibition induced by $10^{-3} \mathrm{M}$ ouabain (in KRP) or $\mathrm{Na}^{+}+\mathrm{K}^{+}$-deprivation (in $\mathrm{KT}$ ), was studied. $\mathrm{Na}^{+}+\mathrm{K}^{+}$free medium was prepared as previously described.

The effects of buffer and Diamox on lactate and ${ }^{14} \mathrm{CO}_{2}$ production. Lactate and ${ }^{14} \mathrm{CO}_{2}$ production were first compared between KT and KRB. The effects of varying concentrations of Diamox $\left(10^{-2} \mathrm{M}-10^{-5} \mathrm{M}\right)$ were then studied on lactate and ${ }^{14} \mathrm{CO}_{2}$ production with $\mathrm{KRB}$ as a medium.

The synergistic effect of Mecholyl and epinephrine. Mecholyl $\left(4.2 \times 10^{-6} \mathrm{M}\right)$ and epinephrine $\left(5.5 \times 10^{-8} \mathrm{M}\right)$ were added to the $\mathrm{KRB}$ either singly or in combination and their effects on lactate and ${ }^{14} \mathrm{CO}_{2}$ production were compared.

Lactate and ${ }^{14} \mathrm{CO}_{2,}$ production of isolated human eccrine sweat glands

After intradermal anesthesia with $1 \%$ procaine, which has no inhibitory effect on monkey sweat gland metabolism, ${ }^{3}$ $1 \times 0.5-\mathrm{cm}$ elliptical skin specimens were excised from the flexor forearm of three healthy men, aged 22-24, and the uninvolved flexor forearm of a 30 -yr-old woman with mild atopic dermatitis. The sweat gland isolation, incubation, and lactate and ${ }^{14} \mathrm{CO}_{2}$ determination were the same as previously described. KRB was used throughout. Since sweat gland size differed markedly from subject to subject in humans, sweat glands were recollected after ${ }^{14} \mathrm{CO}_{2}$ trapping and homogenized, and the mean protein content per gland was measured for each individual by the method of Lowry et al. (8).

\section{RESULTS}

\section{Glucose metabolism of the isolated monkey palm eccrine sweat gland}

The cffect of glucose-free medium on lactate production. The eccrine sweat gland contains glycogen, which shows a variable decrease after sweat secretion (9). $\mathrm{CO}$ : production as determined in the present study would be underestimated if endogenotis (cellular) glycogen or glucose or both provide a considerable portion of the total energy. Since lactate and ${ }^{14} \mathrm{CO}_{2}$ production are quantitatively parallel under aerobic conditions (1), only the former was compared in glucose-free and glucose-containing media to estimate the role of endogenous glycogen or glucose or both as energy sources. As

\footnotetext{
${ }^{3}$ Sato, K. Unpublished observations.
} 
shown in Table I, lactate production in the glucose-free medium was considerably lower than in the glucose-containing medium after pharmacologic stimulation. In the glucose-free medium, Mecholyl or epinephrine failed to stimulate lactate production. After Mecholyl stimulation, lactate production in glucose-free medium was only $3 \%$ of that in glucose-containing medium.

The differential response of the duct and the secretory coil to Mecholyl and epinephrine. Fig. 1 shows lactate and ${ }^{14} \mathrm{CO}_{2}$ production by the coiled duct and the secretory coil. Stimulation of lactate and ${ }^{24} \mathrm{CO}_{2}$ production by Mecholyl or epinephrine occurs only in the secretory coil. Glucose metabolism by the duct was low, unresponsive to Mecholyl or epinephrine, and equal to or slightly lower than in the unstimulated secretory coil.

The effect of $\mathrm{Na}^{+}$and $\mathrm{K}^{+}$deprivation on lactate production. Both sweat secretion and sodium reabsorption are dependent on the energy-requiring, membrane $\left(\mathrm{Na}^{+}\right.$ $\left.+\mathrm{K}^{+}\right)$-ATPase system $(3,4,10,11)$. Both $\mathrm{Na}^{+}$and $\mathrm{K}^{+}$ must be present for the activation of $\left(\mathrm{Na}^{+}+\mathrm{K}^{+}\right)$-ATPase $(3,10)$. As shown in Fig. 2, the omission of either $\mathrm{Na}^{+}$or $\mathrm{K}^{+}$or both produced a lack of activation by Mecholyl but considerable activation by epinephrine. In the $40 \mathrm{mM} \mathrm{Na}^{+}+100 \mathrm{mM} \mathrm{K}{ }^{+}$medium, lactate production was slightly activated by Mecholyl.

The effect of a $40 \mathrm{mM} \mathrm{Na} a^{+}+100 \mathrm{mM} \mathrm{K} \mathrm{K}^{+}$medium on lactate production. Since the assumed intracellular $\mathrm{Na}^{+}$ and $\mathrm{K}^{+}$concentration of the salivary gland is 40 and

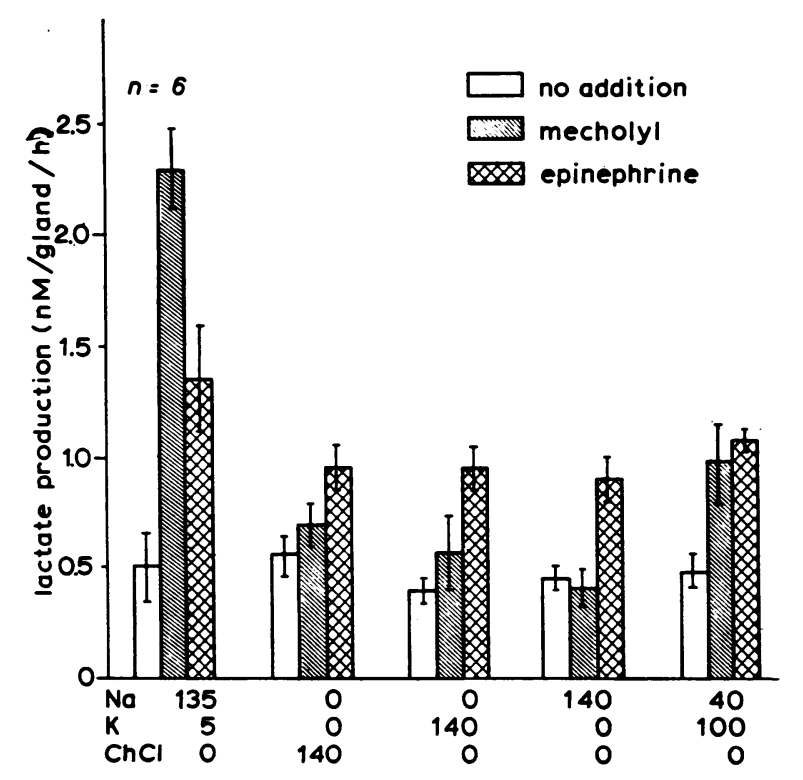

concentrations of $\mathrm{Na}, \mathrm{K}$ and $\mathrm{Ch} \mathrm{Cl}$ in the media ( $\mathrm{mM}$ )

Figure 2 The effect of cations on Mecholyl- or epinephrine-stimulated lactate production. Lactate and ${ }^{14} \mathrm{CO}_{2}$ production are expressed as nanomoles per gland per hour in this and following figures. $\mathrm{ChCl}$, choline chloride.

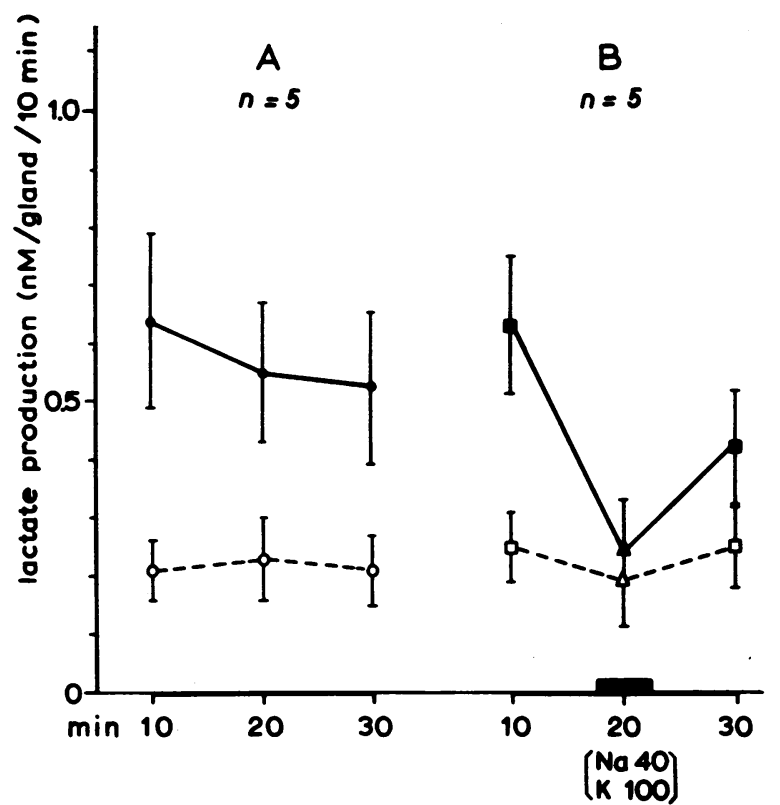

Figure 3 The effect of $40 \mathrm{mM} \mathrm{Na}{ }^{+}+100 \mathrm{mM} \mathrm{K}^{+}$medium on lactate production. Open symbols $(O, \square$, and $\triangle)$ signify unstimulated sweat glands, and closed symbols ( $\bullet$, $\mathbf{D}$, and $\boldsymbol{\Delta}$ ) Mecholyl-stimulated sweat glands. The horizontal bar on the abscissa (B, $20 \mathrm{~min}$ ) signifies the $40 \mathrm{mM}$ $\mathrm{Na}^{+}+100 \mathrm{mM} \mathrm{K}{ }^{+}$medium. $\mathrm{A}$ is the control system, where $\mathrm{KT}$ medium was used throughout the three 10-min incubation periods.

$100 \mathrm{mM}$, respectively $(12,13)$, the effects of these electrolyte concentrations on lactate production were further studied. In this medium, the stimulating effect of Mecholyl on lactate production was markedly suppressed (Fig. 3B, $20 \mathrm{~min}$ ) and was partially restored when the tissue was subsequently transferred to the complete $\mathrm{KT}$ medium.

The effect of DNP on the metabolic inhibition induced by ouabain or $\mathrm{Na}^{+}$and $\mathrm{K}^{+}$deprivation. Both ouabaincontaining and $\mathrm{Na}^{+}$- and $\mathrm{K}^{+}$-free media inhibit $\left(\mathrm{Na}^{+}+\right.$ $\mathrm{K}^{+}$)-ATPase activity (3) and Mecholyl- or epinephrinestimulated glucose metabolism in isolated eccrine sweat glands (1). If the inhibition of energy metabolism by ouabain or $\mathrm{Na}^{+}$and $\mathrm{K}^{+}$deprivation is due solely to their effects on active sodium transport and not to damage to the metabolic machinery secondary to an altered cellular homeostasis, then DNP, an uncoupler of oxidative phosphorylation, should reverse the metabolic inhibition thus incurred. Fig. 4 shows the effect of $10^{-4} \mathrm{M}$ DNP on Mecholyl- or epinephrine-stimulated lactate and ${ }^{14} \mathrm{CO}_{2}$ production. DNP stimulated both lactate and ${ }^{14} \mathrm{CO}_{2}$ production of unstimulated sweat glands. The addition of Mecholyl to DNP further stimulated both ${ }^{14} \mathrm{CO}_{2}$ and lactate production. As illustrated in Fig. 5, $10^{-8} \mathrm{M}$ ouabain alone strongly inhibited both unstimu- 
TABLE II

Effects of Incubation Media on Lactate and $\mathrm{CO}_{2}$ Production

\begin{tabular}{|c|c|c|c|c|c|c|}
\hline & \multicolumn{2}{|c|}{ No drug addition } & \multicolumn{2}{|c|}{$\begin{array}{c}\text { Mecholyl } \\
\left(4.2 \times 10^{-6} \mathrm{M}\right)\end{array}$} & \multicolumn{2}{|c|}{$\begin{array}{c}\text { Epinephrine } \\
\left(5.5 \times 10^{-6} \mathrm{M}\right)\end{array}$} \\
\hline & KR B* & $\mathrm{KT}_{\ddagger}^{\ddagger}$ & KRB & $\mathrm{KT}$ & KRB & kT \\
\hline Lactate $n m o l / g l a n d / h$ & $\begin{array}{r}0.45 \pm 0.10 \\
P>\end{array}$ & $\begin{array}{l}0.63 \pm 0.12 \\
0.2\end{array}$ & $\begin{array}{r}1.77 \pm 0.09 \\
P>\end{array}$ & $\begin{array}{l}1.71 \pm 0.20 \\
0.7\end{array}$ & $\begin{array}{c}1.06 \pm 0.13 \\
0.1<\end{array}$ & $\begin{array}{l}1.33 \pm 0.14 \\
<0.2\end{array}$ \\
\hline $\mathrm{CO}_{2} n m o l / g l a n d / h$ & $\begin{array}{r}0.36 \pm 0.07 \\
P>\end{array}$ & $\begin{array}{l}0.49 \pm 0.09 \\
0.3\end{array}$ & $\begin{array}{c}1.85 \pm 0.14 \\
0.10<1\end{array}$ & $\begin{array}{l}1.53 \pm 0.16 \\
<0.15\end{array}$ & $\begin{array}{c}0.94 \pm 0.16 \\
0.05<\end{array}$ & $\begin{array}{l}1.33 \pm 0.08 \\
<0.10\end{array}$ \\
\hline
\end{tabular}

The results on lactate and ${ }^{14} \mathrm{CO}_{2}$ production are the mean $\pm \mathrm{SE} . \mathrm{M}$ of five experiments.

* Krebs-Ringer bicarbonate.

$\ddagger$ Krebs-Tris buffer.

lated and Mecholyl stimulated lactate and ${ }^{14} \mathrm{CO}_{2}$ production below the baseline level (control "none" in Fig. 5). Epinephrine-stimulated lactate production was slightly higher than the baseline level but ${ }^{14} \mathrm{CO}_{2}$ production was below the control level. The addition of DNP reversed the inhibitory effect of ouabain to approximately $80 \%$ of the Mecholyl-stimulated lactate and ${ }^{14} \mathrm{CO}_{2}$ production ("control-MCH" in Fig. 5). The removal of $\mathrm{Na}^{+}$and $\mathrm{K}^{+}$ from the media resembled the effect of ouabain (Fig. 6). However, the addition of DNP to $\mathrm{Na}^{+}$- and $\mathrm{K}^{+}$-free media enhanced both lactate and ${ }^{14} \mathrm{CO}_{2}$ production to a much smaller extent than in the ouabain-containing complete media.

The effects of buffer and Diamox on lactate and ${ }^{14} \mathrm{CO}$, production. The $\mathrm{KT}$ buffer used in this and previous studies $(1,14)$ lacks $\mathrm{HCO}_{3}^{-}$and $\mathrm{H}_{2} \mathrm{PO}_{4}^{-}$. In some tis-

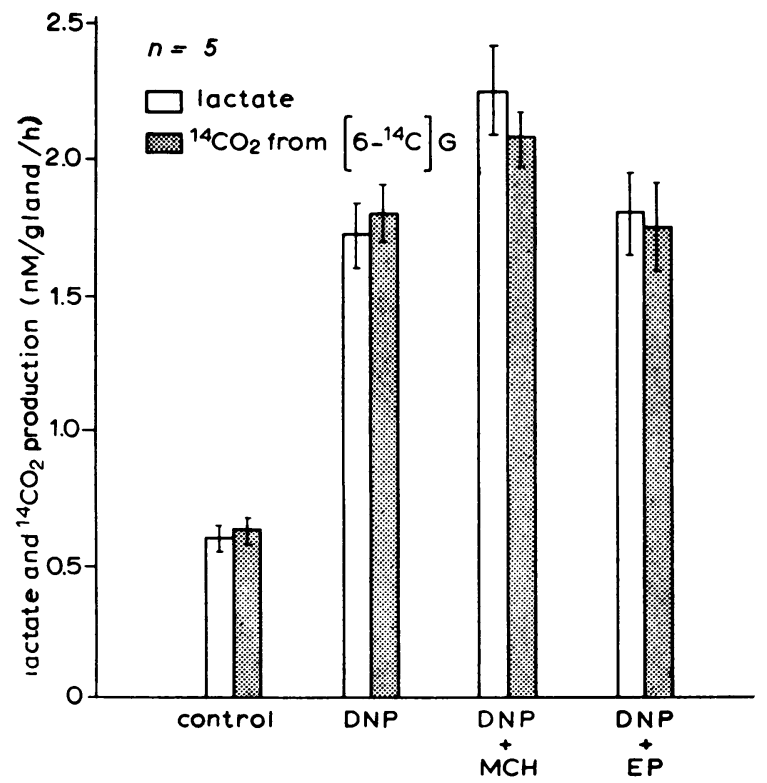

Figure 4 The effect of $10^{-4} \mathrm{M}$ DNP on lactate and ${ }^{14} \mathrm{CO}_{2}$ production. Control means no addition of drugs. sues, the lack of $\mathrm{HCO}_{3}{ }^{-}$and the addition of Diamox lead to a marked decrease in cellular metabolism and function (15). Table II lists lactate and ${ }^{14} \mathrm{CO}_{2}$ production in $\mathrm{KRB}$ and $\mathrm{KT}$ media. ${ }^{14} \mathrm{CO}_{2}$ production in the presence of Necholyl tended to be lower in KT than in KRB, whereas epinephrine-stimulated lactate and ${ }^{14} \mathrm{CO}_{2}$ production tended to be higher in $\mathrm{KT}$ than in $\mathrm{KRB}$, although these were statistically not significant. As shown in Table III a slight inhibitory effect of Diamox on Mecholyl-stimulated ${ }^{14} \mathrm{CO}_{2}$ production was seen only at the highest concentration of Diamox $\left(10^{-2} \mathrm{M}\right)$.

The synergistic effect of Mecholyl and epinephrine on lactate and ${ }^{14} \mathrm{CO}_{2}$ production. Kuno (16) claimed that in man epinephrine potentiates the sudorific action of acetylcholine, whereas Foster Ginsburg, and Weiner (17) could not confirm this. If the sites or mechanisms of action of these drugs differ, some synergistic effect might be expected when both drugs are used simultaneously. As tabulated in Table IV, the addition of epinephrine to Mecholyl failed to enhance Mecholylstimulated lactate and ${ }^{14} \mathrm{CO}_{2}$ production.

Lactate and ${ }^{14} \mathrm{CO}_{2}$ production of isolated human eccrine sweat glands

In this and in a previous communication (1), the monkey palm eccrine sweat gland has been used as a model of the human eccrine sweat gland. Wolfe et al. (14) have claimed that aerobic metabolism accounts for less than $1 \%$ of the total energy production in human eccrine sweat glands. Human as well as monkey sweat glands are well endowed with mitochondria (18), and arterial occlusion causes a sharp decrease in sweat rate and an increase in sweat $\mathrm{Na}^{+}, \mathrm{K}^{+}, 4$ and lactate concentration in human (19). These observations suggest that aerobic metabolism must also play an important role in human eccrine sweat glands. Table $\mathrm{V}$ lists lactate and ${ }^{14} \mathrm{CO}_{2}$ production of isolated human sweat glands in four

\footnotetext{
4 Sato, K. Unpublished observations.
} 


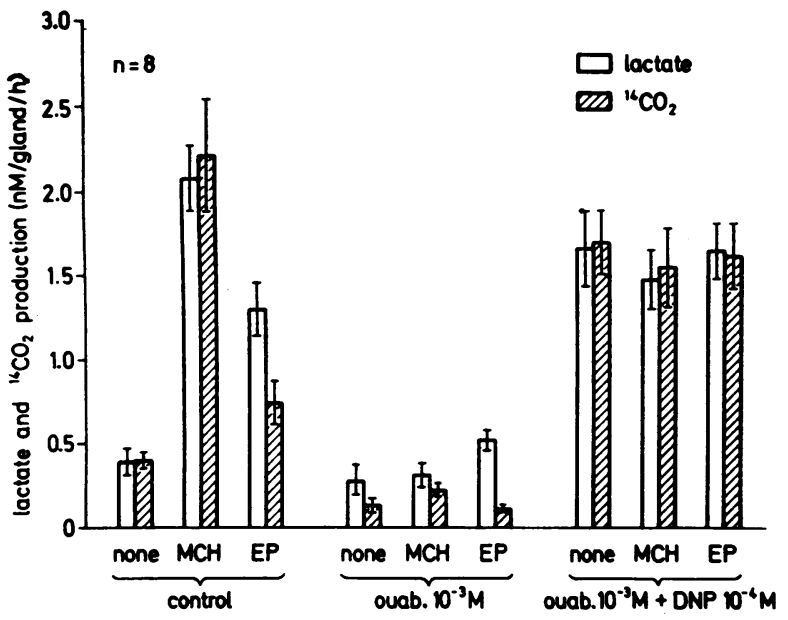

Figure 5 The effect of 2,4-DNP on the ouabain-induced inhibition of lactate and ${ }^{14} \mathrm{CO}_{2}$ production. The concentrations used: ouabain (ouab.) $10^{-3} \mathrm{M}$; DNP, $10^{-4} \mathrm{M}$.

subjects. In contrast to monkey sweat glands, in which molar production rates of lactate and ${ }^{14} \mathrm{CO}_{2}$ are approximately equal, human sweat glands yielded more lactate (from 1.9 to $3.4 \mathrm{nmol} / \mathrm{gland} / \mathrm{h}$ ) and less ${ }^{14} \mathrm{CO}_{2}$ (from 0.42 to $0.72 \mathrm{nmol} / \mathrm{gland} / \mathrm{h}$ ). The mean protein content per gland, and thus their sizes, varied widely (from 1.1 to $2.8 \mu \mathrm{g} / \mathrm{gland}$ ) but the mean of four subjects, $2.3 \mu \mathrm{g} / \mathrm{gland}$, was comparable to that of the monkey sweat gland, $2 \mu \mathrm{g}(3)$.

\section{DISCUSSION}

The whole sweat gland coil (secretory coil plus proximal duct) used to a great extent in the present study consists of five different cell types: clear or secretory, dark, myoepithelial and ductal cells. The metabolic response measured in the whole sweat gland is thus the sum of the metabolic activities of all these cell types. We have assumed, however, that the major portion of the total energy production is related to the secretory and ductal cells since these cells are primarily involved in sodium transport. Furthermore, Mecholyl-induced metabolic stimulation can account for the net sodium flux across the secretory and ductal cells if we assume a $\mathrm{Na}^{+} / \mathrm{ATP}$ ratio of three (3). Eccrine sweat glands are predominantly cholinergic organs, and sweating can be induced by either endogenous or exogenous cholinergic drugs. Although epinephrine and norepinephrine induce sweating (20-23), their physiological and functional significance are as yet enigmatic. The present study has shown that only the secretory coils, innervated by acetylcholinesterase-positive nerves $(18,24)$, respond to Mecholyl and epinephrine in vitro by increases in lactate and ${ }^{14} \mathrm{CO}_{2}$ production and that the ducts, which are not innervated, do not. The effect of
TABLE III

The Effect of Varying Concentrations of Diamox on Lactate and $\mathrm{CO}_{2}$ Production

\begin{tabular}{|c|c|c|c|c|}
\hline \multicolumn{2}{|c|}{ Addition } & \multirow[b]{2}{*}{$n$} & \multicolumn{2}{|c|}{ Production } \\
\hline Mecholyl & Diamox & & Lactate & $\mathrm{CO}_{2}$ \\
\hline & & & nmol/gland/h & $n$ mol/gland/h \\
\hline None & None & 5 & $0.31 \pm 0.02$ & $0.62 \pm 0.09$ \\
\hline $10^{-6} \mathrm{M}$ & None & 5 & $1.50 \pm 0.16$ & $1.94 \pm 0.10^{*}$ \\
\hline $10^{-6} \mathrm{M}$ & $10^{-2} \mathrm{M}$ & 4 & $1.60 \pm 0.12$ & $1.55 \pm 0.06^{*}$ \\
\hline $10^{-6} \mathrm{M}$ & $10^{-3} \mathrm{M}$ & 4 & $1.39 \pm 0.18$ & $1.71 \pm 0.21$ \\
\hline $10^{-6} \mathrm{M}$ & $10^{-5} \mathrm{M}$ & 4 & $1.57 \pm 0.16$ & $2.05 \pm 0.14$ \\
\hline
\end{tabular}

$n$, number of experiments.

${ }^{*} P$ value: $0.05<P<0.10$.

these drugs on cellular metabolism is unlikely to be nonspecific, i.e., unrelated to the cholinergic or adrenergic mechanisms of sweat secretion or due to the direct stimulation of some steps in a metabolic pathway in the duct since it fails to respond to these drugs. A more likely explanation would be that, like the acinar cell of the salivary gland (25), the contraluminal membrane of the secretory cell responds to Mecholyl and perhaps also to epinephrine by an increase in its permeability to external sodium (step 1 in Fig. 7), which in turn stimulates the sodium pump at the luminal (including intercellular canaliculi) side of the membrane (step 2). The stimulation of energy metabolism would then follow (step 3) (26). This assumption is supported by the observations that $\left(\mathrm{Na}^{+}+\mathrm{K}^{+}\right)$-ATPase activity is stimulated exponentially by $\mathrm{Na}^{+}(3)$, and that lactate production is markedly suppressed when the sweat glands are transferred to the $40 \mathrm{mM} \mathrm{Na}{ }^{+}+100 \mathrm{mM} \mathrm{K}^{+}$ medium containing Mecholyl (Fig. 3). Under these circumstances, the concentrations of sodium and potassium

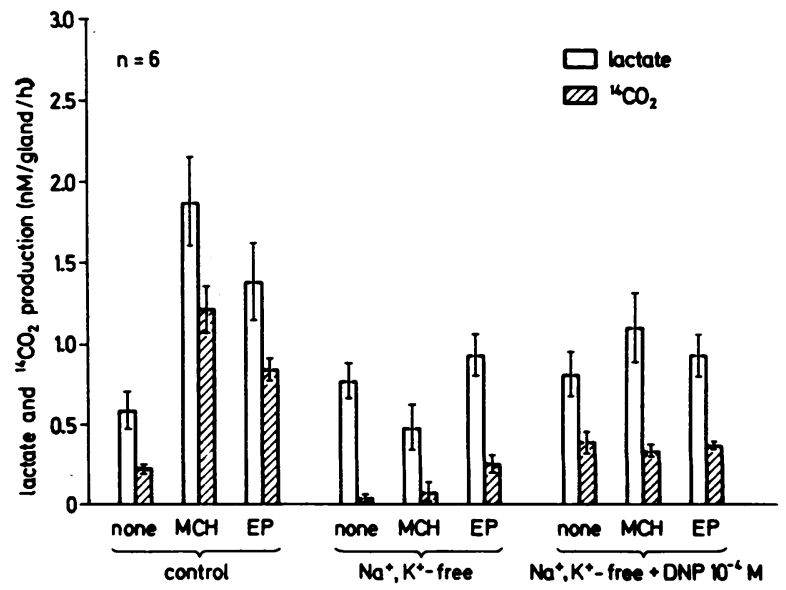

Figure 6 The effect of DNP on the metabolic inhibition induced by $\mathrm{Na}^{+}$and $\mathrm{K}^{+}$deprivation. 
TABLE IV

The Effect of Epinephrine on Mecholyl-Stimulated Lactate and $\mathrm{CO}_{2}$ Production

\begin{tabular}{|c|c|c|c|c|}
\hline & No drug addition & $\begin{array}{c}\text { Mecholy.1 } \\
\left(4.2 \times 10^{-6} \mathrm{M}\right)\end{array}$ & $\begin{array}{l}\text { Epinephrine } \\
\left(5.5 \times 10^{-6} \mathrm{M}\right)\end{array}$ & $\begin{array}{c}\text { Mecholyl } \\
\left(4.2 \times 10^{-6} \mathrm{M}\right) \\
+ \\
\text { Evinephrine } \\
\left(5.5 \times 10^{-6} \mathrm{M}\right)\end{array}$ \\
\hline Lactate $n \mathrm{~mol} / \mathrm{gland} / \mathrm{h}$ & $0.68 \pm 0.07$ & $2.24 \pm 0.26^{*}$ & $1.31 \pm 0.18$ & $2.20 \pm 0.15^{*}$ \\
\hline${ }^{14} \mathrm{CO}_{2} \mathrm{nmol} / \mathrm{gland} / \mathrm{h}$ & $0.31 \pm 0.08$ & $2.39 \pm 0.39 \ddagger$ & $0.79 \pm 0.11$ & $2.25 \pm 0.22 \ddagger$ \\
\hline
\end{tabular}

The mean \pm SEM of eight experiments.

$* P>0.8$.

$\ddagger P>0.7$.

are approximately equal inside and outside of the cell, so that Mecholyl-induced alterations in membrane permeability produce little or no net sodium influx (step 1 ), leading to much lower activation of steps 2 and 3 . The absence of a synergistic effect between Mecholyl and epinephrine on lactate and ${ }^{14} \mathrm{CO}_{2}$ production suggests that both drugs act at the same site, probably at step 1 , since neither Mecholyl nor epinephrine are stimulants of $\left(\mathrm{Na}^{+}+\mathrm{K}^{+}\right)$-ATPase. ${ }^{5}$ However, the failure to completely abolish the epinephrine-stimulated lactate production by the highest concentration of ouabain $\left(10^{-3} \mathrm{M}\right)$ (1), by nitrogenated media (1), or by $\mathrm{Na}^{+}$- and $\mathrm{K}^{+}$-free media suggests that at least part of the epinephrine-induced metabolic stimulation is independent of the linkage between steps 2 and 3 . This action of epinephrine cannot be explained by its effect on the adenylcyclasecyclic AMP system since neither dibutyryl cyclic AMP nor theophylline nor a combination of both enhances lactate or ${ }^{14} \mathrm{CO}_{2}$ production (from $\left[6-{ }^{14} \mathrm{C}\right]$ glucose) (7). As shown in Figs. 4-6, DNP, an uncoupler of oxidative phosphorylation (27-29), stimulated lactate and ${ }^{{ }^{14}} \mathrm{CO}_{2}$ production almost as effectively as Mecholyl, and also

${ }^{5}$ Sato, K. Unpublished observations. reversed the ouabain-induced inhibition of glucose metabolism. These effects of DNP are to be expected since uncoupling of oxidation from phosphorylation produces high cellular ADP levels (since ATP is not formed or is quickly hydrolyzed to ADP even if formed), which in turn enhance glycolysis (30) as well as oxidative phosphorylation (31). Furthermore, the reversal of ouabain-induced inhibition of glucose metabolism by DNP points to the specificity of the effect of ouabain on sodium transport and the tightness of the coupling between glucose oxidation (Fig. 7, step 3) and ATP utilization for sodium transport (step 2). If the metabolic inhibition by ouabain simply represents damage to the metabolic machinery caused either directly by ouabain or by alteration of cellular electrolyte balance (increase of $\mathrm{Na}^{+}$and decrease of $\mathrm{K}^{+}$), then the stimulation of glucose metabolism in the presence of both ouabain and DNP is unexplained. The in vivo effects of ouabain on both sweat secretion and $\mathrm{Na}^{+}$reabsorption have been previously studied (11). The action of ouabain on sweat gland sodium transport (11) and glucose metabolism supports our earlier postulates that both sweat secretion by the secretory cells and $\mathrm{Na}^{+}$reabsorption by the ductal cells are mediated by a $\left(\mathrm{Na}^{+}+\mathrm{K}^{+}\right)$-ATPase-depen-

TABLE V

Lactate and $\mathrm{CO}_{2}$ Production of Isolated Human Forearm Eccrine Sweat Glands

\begin{tabular}{|c|c|c|c|c|c|c|c|c|c|}
\hline \multirow[b]{2}{*}{ Sub. } & \multirow[b]{2}{*}{ Age } & \multirow[b]{2}{*}{ Sex } & \multirow[b]{2}{*}{ Protein* } & \multicolumn{3}{|c|}{ Lactate } & \multicolumn{3}{|c|}{$\mathrm{CO}=$} \\
\hline & & & & $\mathrm{C}$ & $\mathrm{MCH}$ & $\mathrm{EP}$ & C & $\mathrm{MCH}$ & EP \\
\hline & & & $\mu g / g l a n d$ & \multicolumn{3}{|c|}{$n$ mol/gland $h$} & \multicolumn{3}{|c|}{$\mathrm{nmol} / \mathrm{gland} / \mathrm{h}$} \\
\hline 1 & 30 & $\mathrm{~F}$ & 2.4 & 0.72 & 2.86 & 1.30 & 0 & 0.47 & 0.14 \\
\hline 2 & 22 & $\mathrm{M}$ & 1.1 & 0.11 & 1.90 & 1.30 & 0 & 0.42 & 0.31 \\
\hline 3 & 22 & $\mathrm{M}$ & 2.8 & 0.92 & 3.40 & 3.10 & 0 & 0.72 & 0.46 \\
\hline 4 & 24 & M & 2.7 & 0.80 & 3.40 & 2.60 & 0 & 0.60 & 0.43 \\
\hline \multicolumn{2}{|c|}{ Mean } & & 2.3 & 0.66 & 2.90 & 2.08 & 0 & 0.55 & 0.34 \\
\hline
\end{tabular}

$\mathrm{C}$, control (unstimulated); $\mathrm{MCH}$, Mecholyl $\left(4.2 \times 10^{-4} \mathrm{M}\right) ; \mathrm{EP}$, epinephrine $\left(5.5 \times 10^{-5} \mathrm{M}\right)$.

* Mean protein content per gland. Experiments were performed in March and May 1971 in the

Netherlands. 


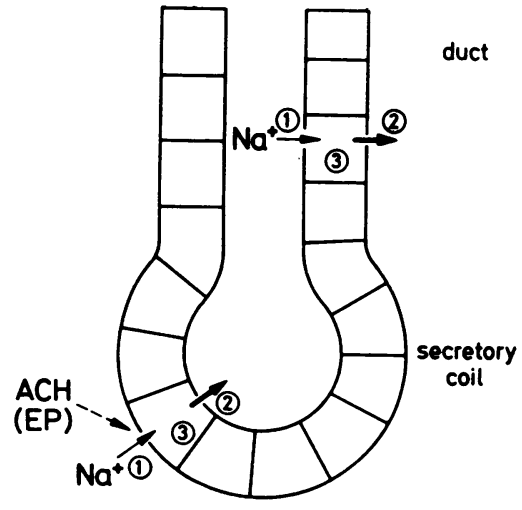

FIGURE 7 A schematic drawing of the three major steps in sodium secretion by the secretory coil and sodium reabsorption by the duct. Step 1 , passive entry of $\mathrm{Na}^{+}$; step 2, sodium pump ([Na $+\mathrm{K}]-A T P a s e)$; step 3 , energy metabolism; $\mathrm{ACH}$, acetylcholine; EP, epinephrine.

dent $\mathrm{Na}^{+}$pump $(3,4)$. The reversal by DNP of the metabolic inhibition caused by $\mathrm{Na}^{+}$and $\mathrm{K}^{+}$deprivation was only partial.This may indicate that $\mathrm{Na}^{+}$and $\mathrm{K}^{+}$deprivation caused irreversible damage to the cellular metabolic machinery or that uncoupling by DNP was incomplete, since DNP-sensitive, mitochondrial ATPase requires $\mathrm{K}^{+}$for its maximal activity (32). A third possibility is that the glucose entry into the cell is coupled to $\mathrm{Na}^{+}$influx and is thus inhibited in a $\mathrm{Na}^{+}-$and $\mathrm{K}^{+}$-free medium. However, this seems unlikely to be the cause of the low reversal by DNP of metabolic inhibition in the $\mathrm{Na}^{+}-+$ $\mathrm{K}^{+}$-free media, since in the absence of $\mathrm{Na}^{+}$transport, as in the case after the addition of DNP to the unstimulated sweat gland (Fig. 6), sufficient glucose was available in the cell to stimulate glucose metabolism maximally. The failure of Diamox or a bicarbonate-free medium to significantly reduce sweat gland glucose metabolism suggests that hydrogen-ion transport does not play a major role at all stages of sodium transport.

In disagreement with the results of Wolfe et al (14), the present study showed considerable ${ }^{14} \mathrm{CO}_{2}$ production by human forearm sweat glands although the mean ${ }^{14} \mathrm{CO}_{2}$-to-lactate ratio after Mecholyl stimulation of 0.21 is only one-fifth that of monkey palm sweat glands (1). If we assuming $6 \mathrm{~mol} \mathrm{CO}_{2}$ is equivalent to $38 \mathrm{~mol} \mathrm{ATP}$, and $1 \mathrm{~mol}$ lactate to $1 \mathrm{~mol}$ ATP, human forearm sweat glands produce a mean ATP of $3.5 \mathrm{nmol} /$ gland/h by oxidation and $2.9 \mathrm{nmol} / \mathrm{gland} / \mathrm{h}$ by glycolysis. The higher activity of the oxidative pathway in monkey palm sweat glands may be due partly to a species difference and partly to the fact that sweating on the palm in the monkey occurs almost continuously (33) whereas the thermally-responsive sweat glands of man are relatively inactive in a temperate climate during the months of March to May when these studies were performed.
The disagreement between our results and those of Wolfe et al. (14) can be partly explained since Wolfe et al. incubated sweat glands in a glucose-free medium to measure $\mathrm{O}_{2}$ consumption whereas we used a glucosecontaining medium.

\section{ACKNOWLEDGMENTS}

We would like to thank Profs. J. F. G. Slegers (Department of Physiology) and J. W. H. Mali (Department of Dermatology), University of Nijmegen, for their kind support and encouragement for this study, and Dr. K. J. Ullrich (MaxPlanck-Institut, Frankfurt) for the critical reading of the paper.

This work was aided in part by U. S. National Institute of Health grant AM-05655 and Training Grant 5-TI-AM5300 .

\section{REFERENCES}

1. Sato, K., and R. L. Dobson. 1971. Glucose metabolism of the isolated eccrine sweat gland. I. The effects of Mecholyl, epinephrine and ouabain. J. Invest. Derm. 56: 272.

2. Lehninger, A. L. 1965. The molecular basis of biological energy transformation. Bioenergetics. W. A. Benjamin, Inc., New York. 102.

3. Sato, K., J. W. H. Mali, and R. L. Dobson. 1971. Enzymatic basis for the active transport of sodium in the eccrine sweat gland; Localization and characterization of $\mathrm{Na}$-K-adenosine triphosphatase. J. Invest. Derm. $57: 10$.

4. Sato, K., and R. L. Dobson. 1970. Enzymatic basis for the active transport of sodium in the duct and secretory portion of eccrine sweat gland. J. Invest. Derm. 55: 53 .

5. Adachi, K., and H. Uno. 1968. Glucose metabolism of growing and resting human hair follicles. Am.J. Physiol. 215 : 1234.

6. Lundholm, L., E. Mohme-Lundoholm, and N. Vamos. 1963. Lactic acid assay with L- $(+)$ lactic acid dehydrogenase from rabbit muscle. Acta Physiol. Scand. 58: 243 .

7. Sato, K. 1973. Stimulation of pentose cycle in the eccrine sweat gland by adrenergic drugs. Am. J. Physiol. 224: 1149 .

8. Lowry, O. H., N. J. Rosebrough, A. L. Farr, and J. R. Randall. 1951. Protein measurement with folin phenol reagent. J. Biol. Chem. 193: 265.

9. Dobson, R. L. 1962. The correlation of structure and function in the human eccrine sweat gland. Adi. Biol. Skin. 3: 54 .

10. Skou, J. C. 1965. Enzymatic basis for active transport of $\mathrm{Na}^{+}$and $\mathrm{K}^{+}$across cell membranes. Physiol. Rev. 45: 596.

11. Sato, K., J. R. Taylor, and R. L. Dobson. 1969. The effect of ouabain on eccrine sweat gland function. $J$. Invest. Derm. 53: 275 .

12. Burgen, A. S. V. 1956. The secretion of potassium in saliva. J. Physiol. $132: 20$.

13. Schneyer, L. H., and C. A. Schneyer. 1962. Influence of pilocarpine on transport of salivary gland slices. Am. J. Physiol. 205 : 1058.

14. Wolfe, S., G. Cage, M. Epstein, L. Tice, H. Miller, and R. S. Gordon, Jr. 1970. Metabolic studies of isolated human eccrine sweat glands. J. Clin. Invest. 49: 1880 . 
15. Diamond, M. 1964. Transport of salt and water in rabbit and guinea pig gall bladder. J. Gen. Physiol. 48: 1.

16. Kuno, Y. 1965. The mechanism of human sweat secretion. Proceedings of the 23rd International Congress of Physiological Science, Tokyo. 3.

17. Foster, K. G., J. Ginsburg, and J. S. Weiner. 1970. Role of circulating catecholamines in human eccrine sweat gland control. Clin. Sci. (Oxf.). 39: 823 .

18. Ellis, R. A. 1968. Eccrine sweat glands: electron microscopy, cytochemistry and anatomy. In Normale und Pathologische Anatomie der Haut. I. Handbuch der Haut- und Geschlechtskrankheiten. J. Jadassohn, editor. Springer-Verlag. GmbH. Berlin. Vol. 1. 224.

19. Weiner, J. S., and R. E. Van Heynigen. 1952. Observation on lactate content of sweat. J. Appl. Physiol. 4: 734.

20. Haimovici, H. 1950. Evidence for adrenergic sweating in man. J. Appl. Phy'siol. 2: 512.

21. Wada, M. 1950. Sudorific action of adrenaline on the human sweat glands and determination of their exitability. Science (Wash. D. C.). 111: 376.

22. Chalmers, T. M., and C. A. Keele. 1951. Physiological significance of the sweat response to adrenalin in man. J. Physiol. 114 : 510.

23. Lloyd, D. P. C. 1959. Response of cholinergically innervated sweat glands to adrenaline and noradrenaline. Nature (Lond.). 184 : 277.

24. Montagna, IV. 1962. Histological, histochemical and pharmacological properties. Fccrine sweat glands and eccrine sweating. Adr. Biol. Skin. 3: 6.

25. Petersen, O. H. 1970. The ionic transport involved in the acetylcholine-induced change in membrane potential and their importance in the salivary secretion process.
Symposia Medica Hoechst. In Electrophysiology of Epithelial Cells. G. Giebisch, editor. Friedrich-Karl Schattauer-Verlag, Stuttgart. 209.

26. Hokin, M. R. 1966. Respiration and ATP and ADP levels during $\mathrm{Na}^{+}$transport in salt gland slices. Life Sci. $5: 1829$.

27. Mitchell, P. 1966. Chemiosmotic coupling in oxidative photosynthetic phosphorylation. Biol. Rea. (Camb.). 41: 445.

28. Mitchell, P., and J. Moyle. 1969. Estimation of membrane potential and $\mathrm{pH}$ difference across the cristae membrane of rat liver mitochondria. Eur. J. Biochem. $7: 471$.

29. Slater, E. C., and H. F. Ter Welle. 1969. Application of oligomycin and related inhibitors in bioenergetics. In inhibitors as tools in cell research. Colloq. Ges. Biol. Chem. 20: 258.

30. Parker, J. C., and J. F. Hoffman. 1967. The role of membrane phosphoglycerate kinase in the control of glycolytic rate by active cation transport in human red blood cell. J. Gen. Physiol. 50: 893.

31. Loewenstein, J. M. 1967. The tricarboxylic acid cycle In Metabolic Pathways. D. M. Greenberg, editor. Academic Press, Inc., New York. 3rd ed., 146.

32. Gómez-Puyou, A., F. Sandoval, M. Tuena de GómezPuyou, A. Peña, and E. Chávez. 1971. Dependency of the 2,4-dinitrophenol-stimulated ATPase activity on $\mathrm{K}^{+}$ and respiration. Biochem. Biophys. Res. Commun. 45: 104.

33. Kuno, Y. 1956. Perspiration of the palms and soles and the effect of mental stress on perspiration in general. Human Perspiration. Charles C. Thomas Publisher, Springfield, Ill. 141 . 